\title{
MULTIDIMENSIONAL HARDY-TYPE INEQUALITIES ON TIME SCALES WITH VARIABLE EXPONENTS
}

\section{O. O. Fabelurin, J. A. Oguntuase and L.-E. Persson}

Abstract. A new Jensen inequality for multivariate superquadratic functions is derived and proved. The derived Jensen inequality is then employed to obtain the general Hardy-type integral inequality for superquadratic and subquadratic functions of several variables.

Mathematics subject classification (2010): 26D10, 26D20, 26E70.

Keywords and phrases: Multidimensional inequalities, Jensen's inequality, Hardy-type inequalities, time scales, superquadratic functions.

\section{REFERENCES}

[1] R. P. Agarwal, M. Bohner and N. Peterson, Inequalities on time scales: a survey, Math. Inequal. Appl. 4 (2001), 535-557.

[2] R. P. Agarwal, D. O'Regan and S. H. SAKar, Dynamic inequalities on time scales, Springer, Heidleberg/New York/Drodrechet/London, 2014.

[3] R. P. Agarwal, D. O'Regan and S. H. Sakar, Hardy type inequalities on time scales, Springer International Publishing, Switzerland, 2016.

[4] M. ANWAR, R. BIBI, M. BOHNER AND J. E. PEČARIĆ, Jensen's functional on time scales for several variables, Int. J. Anal. 2014 (2014), 14pp.

[5] R. Bibi, M. Bohner, J. E. PeČarić And S. VarošAnec, Minkowski and Beckenbach-Dresher inequalities and functionals on time scales, J. Math. Inequal. 7 (2013), no. 3, 299-312.

[6] M. Bohner And A. Peterson (eds.), Dynamic equations on time scales: An Introductin with Applications, Birkh ä user, Boston, Massachusetts, 2001.

[7] M. Bohner AND A. Peterson (EDS.), Advances in Dynamic equations on time scales, Birkhä user, Boston, Massachusetts, 2003.

[8] T. Donchev, A. Nosheen And J. E. PeČARIĆ, Hardy-Type inequalities on time scales via convexity in several variables, ISRN Math. Anal. 2013 (2013), 9pp.

[9] G. H. HARDY, Notes on a theorem of Hilbert, Math. Z. 6 (1920), 314-317.

[10] G. H. HARDY, Notes on some points in the integral calculus, LX. An inequality between integrals, Messenger Math. 54 (1925), 150-156.

[11] G. H. Hardy, J. E. Littlewood and G. Pólya, Inequalities, Cambridge University Press, Cambridge, 1959.

[12] S. Hilger, Ein Maßkettenkalkül mit Anwendung auf Zentrumsmannigfaltigkeiten, $\mathrm{PhD}$ thesis,

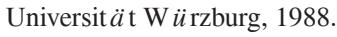

[13] S. Hilger, Differential and difference calculus, Nonlinear Anal., Proceedings of Second World Congress of Nonlinear Analysts, 30 (5), (1997), 2683-2694.

[14] S. HILGER, Analysis on measure chains-a unified approach to continuous and discrete calculus, Results Math. 18 (1990), no. 1-2, 18-56.

[15] A. Kufner, L. Maligranda And L. - E. Persson, The prehistory of the Hardy inequality, Amer. Math. Monthly 113 (2006), no. 10, 715-732.

[16] A. Kufner, L. Maligranda And L. - E. Persson, The Hardy Inequality. About its History and Some Related Results, Vydavatelsky Servis Publishing House, Pilsen, 2007.

[17] A. Kufner, L. - E. Perss on And N. SAmKo, Weighted Inequalities of Hardy type, Second Edition, World Scientific Publishing Co. Inc., River Edge, New Jersey, 2017. 
[18] J. A. Oguntuase And L. E. Persson, Time scales Hardy-type inequalities via superquadraticity, Ann. Funct. Anal. 5 (2014), no.2, 61-73.

[19] P. $\breve{R} \mathrm{EH} a ́ \mathrm{~K}$, Hardy inequality on time scales and its application to half-linear dynamic equations, J. Inequal. Appl. 5 (2005), 495-507. 